\title{
Progressive Normalization of Growth Hormone-Binding Protein and IGF-I Levels in Treated Growth Hormone-Deficient Children*
}

\author{
JULIANE LEGER, MICHÈLE NOEL, PAUL CZERNICHOW, AND \\ MARIE-CATHERINE POSTEL-VINAY
}

\author{
Department of Pediatric Endocrinology and Diabetes, Hopital Robert Debré [J.L., M.N., P.C.] and \\ INSERM Unité 344, Molecular Endocrinology, Hopital Necker-Enfants Malades, Paris, France [M.-C.P.-V.]
}

\begin{abstract}
The short- and long-term effects of hGH treatment on growth hormone (GH)-binding protein (GHBP) were examined in 18 prepubertal children, aged 1.5-10 y, with isolated idiopathic $\mathrm{GH}$ deficiency. The patients were studied before and at regular intervals during $24 \mathrm{mo}$ of hGH therapy $(0.6 \mathrm{IU} / \mathrm{kg} / \mathrm{wk}$, given daily). Pretreatment GHBP values were low: $14.6 \pm 1.2 \%$ of radioactivity ( $p<0.0001$ versus normal prepubertal children). After the first hGH injection, GHBP levels fell significantly at 6 $\mathrm{h}(8.2 \pm 1.3 \%$ of radioactivity) and then remained at basal level during the first week. Under hGH therapy, an increase in GHBP was observed, but it occurred at different times of treatment, from 1 to $12 \mathrm{mo}$, and the mean GHBP value became significantly higher than the value before treatment after 12 mo of therapy. An
\end{abstract}

ABSTRACT

increase in serum IGF-I level was observed as soon as 1 wk of hGH therapy, and after $3 \mathrm{mo}$, the mean IGF-I value was normal. No correlation was found between the increase in GHBP, IGF-I levels, and the growth velocity at 12 and 24 mo of treatment. These findings support the role of $\mathrm{GH}$ in the regulation of GHBP/receptor in man. The time course of the GH effect appears to be progressive and variable. (Pediatr Res 37: 731-735, 1995)
GH, growth hormone
Abbreviations
GHBP, growth hormone-binding protein
BMI, body mass index

Identification of the serum GHBP and demonstration that the amino acid sequence of GHBP is identical to that of the extracellular domain of the membrane GH receptor have provided new tools to study $\mathrm{GH}$ action in man $(1,2)$. In clinical research, measurement of serum GHBP is the only approach to estimate the $\mathrm{GH}$ receptor because there are no accessible cells in which GH receptors can be measured. In man, GHBP probably results from proteolytic cleavage of the membrane receptor as no specific mRNA for the short form of the $\mathrm{GH}$ receptor is detected in human tissues (3). The plasma GHBP level is believed to reflect the concentration of tissue $\mathrm{GH}$ receptors. In animal models, $\mathrm{GH}$ receptors have been shown to be modified in several pathologic situations (4). As membrane $\mathrm{GH}$ receptors are regulated by many factors, the level of plasma GHBP is expected to be under a multifactorial control.

Among many factors, $\mathrm{GH}$ has been shown to play an important role in the regulation of its receptors. However, a controversy has recently arisen concerning the effect of $\mathrm{GH}$ on

Received September 8, 1994; accepted December 20, 1994

Correspondence: Dr. M-C Postel-Vinay, INSERM Unité 344, Faculté de Médecine Necker, 156 Rue de Vaugirard, 75730 Paris Cedex 15, France.

* This work was presented in part at the Joint Meeting of LWPES/ESPE, San Francisco, June 1993 (Abstract 356). the plasma $\mathrm{GH}$ binding activity. On one hand, $\mathrm{GH}$ is able to increase GHBP levels, as was shown in children with $\mathrm{GH}$ deficiency $(5,6)$ and also in children with idiopathic short stature (7). On the other hand, absence of GH effect on GHBP has been reported in treated $\mathrm{GH}$-deficient children (8).

In this work, we have examined short-term and long-term effects of hGH treatment in prepubertal children with isolated GH deficiency. GHBP was measured longitudinally before treatment and during 24 mo after the beginning of GH therapy. Short-term effects of hGH may represent an important issue as they could be used to better predict response to hGH therapy in physiopathologic situations.

\section{METHODS}

Subjects and protocol. Eighteen prepubertal children (11 boys and 7 girls), aged 1.5-10 y (mean age: $5.6 \pm 2.9 \mathrm{y}$ ), with isolated idiopathic GH deficiency, were studied before treatment and at regular intervals during the first $2 \mathrm{y}$ of $\mathrm{hGH}$ therapy. GH deficiency was defined as subnormal GH responses to at least two provocative tests (peak GH $<10 \mu \mathrm{g} / \mathrm{L}$ ), which was chosen by the French Pituitary Agency for providing hGH therapy. Recombinant hGH (Saizen, Serono Laboratories and Genotonorm, Kabi Pharmacia Laboratories) was 
given s.c. daily, at the dosage of $0.60 \mathrm{IU} / \mathrm{kg} / \mathrm{wk}$. All but four subjects were followed longitudinally for $2 \mathrm{y}$ of treatment. Patient 14 could not be followed after 6 mo of therapy, and three patients (nos. 1, 8, and 11) were studied for $1 \mathrm{y}$ only. Three patients (nos. 13,17, and 18) entered puberty between 18 and 24 mo of the treatment; for that reason and for that time period, results for these patients were not included. Height and weight were measured before treatment and every 3 mo on hGH treatment. Height was expressed as the SD score (SDS) for chronologic age (9). Weight for height was expressed as body mass index $\left[\mathrm{BMI}=\right.$ weight $\left.(\mathrm{kg}) / \mathrm{height}\left(\mathrm{m}^{2}\right)\right]$ in $\mathrm{SD}$ for chronologic age (10). Growth velocities were calculated 12 mo after beginning hGH therapy by subtracting the height at baseline from the height at $12 \mathrm{mo}$. The clinical characteristics of patients are presented in Table 1.

The 18 patients were investigated for biologic parameters before and 6,12 , and 24 mo after the onset of hGH treatment. The short-term response to the hGH treatment was evaluated in 10 of them, and blood samples were collected before and at 6 , 12,24 , and $48 \mathrm{~h}, 8 \mathrm{~d}$, and 1 and $3 \mathrm{mo}$ after the beginning of treatment. For technical reasons, some blood samples could not be obtained for all measurements. After the first $48 \mathrm{~h}$ of treatment, sampling was performed between 14 and $20 \mathrm{~h}$ after the last hormone injection.

Informed consent was obtained from the parents.

Procedures. Blood samples were collected during the study period, and sera were stored at $-20^{\circ} \mathrm{C}$ until assayed. Periodic samples were measured in the same assay.

GHPB was measured by HPLC-gel filtration, as previously described (11). Briefly, $100 \mu \mathrm{L}$ of serum were incubated with $100 \mu \mathrm{L}$ of potassium phosphate, $0.1 \mathrm{M}, \mathrm{pH} 7.0$, containing ${ }^{125} \mathrm{I}$-hGH $\left(1 \times 10^{5} \mathrm{cpm}\right)$. After $20 \mathrm{~h}$ at $4^{\circ} \mathrm{C}$, the incubation was injected onto HPLC Protein Pak 300 sw column (Waters, Milford, MA). Elution was performed isocratically using degassed buffer pumped at a rate of $0.5 \mathrm{~mL} / \mathrm{min}$. Radioactivity was recorded on line using a Berthold LB $504 \gamma$ detector connected to a computer. To evaluate nonspecific binding, 2 $\mu \mathrm{g}$ of hGH were added to the incubation. The binding of ${ }^{125} \mathrm{I}$-hGH is expressed as the percentage of total radioactivity (radioactivity in the individual peak divided by total radioactivity in the peaks). The interassay coefficient of variation was $8 \%$ (11). In some serum samples, the GH concentration was elevated, and the binding of ${ }^{125} \mathrm{I}-\mathrm{hGH}$ to GHBP had to be corrected for occupancy of the receptor by GH. Such a correction was done for samples containing $\mathrm{GH}$ at a concentration

Table 1. Growth parameters of the group of 18 children with isolated GH deficiency before and after 12 and 24 mo of GH treatment

\begin{tabular}{lcccc}
\hline & $\begin{array}{c}\text { Height } \\
\text { (SDS) }\end{array}$ & $\begin{array}{c}\text { Growth } \\
\text { velocity } \\
(\mathrm{cm} / \mathrm{y})\end{array}$ & $\begin{array}{c}\text { Growth } \\
\text { velocity } \\
\text { (SDS) }\end{array}$ & $\begin{array}{c}\text { BMI } \\
\text { (SDS) }\end{array}$ \\
\hline Baseline & $-3.3 \pm 1.3$ & $4 \pm 1.4$ & $-2.6 \pm 1.3$ & $-0.3 \pm 1.1$ \\
$12 \mathrm{mo}$ & $-2.3 \pm 1.1^{*}$ & $9.5 \pm 1.9^{*}$ & $3.3 \pm 1.8^{*}$ & $-0.8 \pm 0.9^{* * *}$ \\
$24 \mathrm{mo}$ & $-1.8 \pm 1.1^{* *}$ & $7.0 \pm 1.4^{* * *}$ & $1.1 \pm 0.9^{* *}$ & $-0.9 \pm 0.9$ \\
\hline
\end{tabular}

Results are expressed as mean \pm SD. SDS $=$ SD score.

${ }^{*} p=0.0002$ vs baseline; ${ }^{* *} p=0.003$ vs baseline; ${ }^{* * *} p=0.01$ vs baseline.
$>6 \mu \mathrm{g} / \mathrm{L}$, as previously reported (5); this was the case for all blood samples collected $6 \mathrm{~h}$ after the first GH injection and for one sample collected at $12 \mathrm{~h}$.

None of the patients of the study group developed detectable $\mathrm{GH}$ antibodies as observed on the elution profiles from HPLCgel filtration of ${ }^{125} \mathrm{I}-\mathrm{hGH}$ incubated with serum. The $\mathrm{GH}$ concentration was measured by immunoradiometric assay using polyclonal antibodies (Pharmacia, Saint-Quentin en Yvelines, France). IGF-I was measured by RIA, after acid gel filtration (12). IGF-I antibody was kindly donated by Dr. P. Chatelain, Lyon, France.

Statistics. Results are expressed as mean \pm SEM. Statistical differences between groups were assessed using variance analysis. If overall significant differences were present, specific differences between two time periods were sought by the Wilcoxon signed rank test (with a Bonferroni correction for simultaneity). The Mann-Whitney $U$ test was used to compare data in two different groups. Correlation between variables was evaluated by linear regression analysis.

\section{RESULTS}

In 18 children with isolated GH deficiency, basal GHBP values were lower $(14.6 \pm 1.2 \%$ of radioactivity, $p<0.001)$ than in normal prepubertal children (mean value in a group of 15 prepubertal normal children: $24.8 \pm 1.7 \%$ ) (11). As shown in Table 2, values ranged from 7.0 to $25.4 \%$ of radioactivity. In this group of prepubertal children, no relationship was found between GHBP levels and chronologic or bone age. However, a positive correlation was found between GHBP levels and BMI before treatment, as shown in Fig. $1(r=0.63, p=$ 0.005).

GHBP and GH levels for $48 \mathrm{~h}$ after the first hGH injection are presented in Fig. 2. In the group of 10 children studied for the short-term hGH response, the GH peak at $6 \mathrm{~h}$ was associated with a significant decrease in GHBP $(p<0.005)$. Both $\mathrm{GH}$ and GHBP returned to baseline $24 \mathrm{~h}$ after the first hGH injection (Fig. 2 and Table 3). Under hGH treatment, an increase in GHBP was observed in all patients but two (patients 10 and 14); however, in one patient GHBP could not be assayed after 6 mo of treatment and in the other one, GHBP was normal before hGH therapy. Increase in GHBP occurred slowly and at different times of GH therapy: in the group of 10 patients evaluated for the short-term hGH response (Table 3), it was observed after 1 mo for two patients, at 3 mo for one patient, at 6 mo for one patient, and thereafter $(12$ or even 24 mo) for the others. As shown in Fig. 3 and Table 2, when results for all patients were analyzed, the mean GHBP value became significantly higher than the value before treatment after 12 mo of therapy $(p=0.006)$. The difference between 12 and 24 mo was not significant.

As expected, plasma IGF-I concentrations were low before treatment $(42 \pm 5.8 \mu \mathrm{g} / \mathrm{L}, p=0.0001$ versus normal children). Increase in IGF-I occurred sooner than increase in GHBP (Fig. $3)$ : it was significant after $8 \mathrm{~d}$ of hGH therapy $(p<0.02)$. At 3 mo of treatment, the mean serum IGF-I level was normal and reached a plateau thereafter. There was no significant difference between IGF-I levels at 3, 6, 12, and 24 mo. No correla- 
Table 2. GHBP values in 18 children with isolated GH deficiency, before and during the first 2 y of hGH therapy

\begin{tabular}{|c|c|c|c|c|c|c|}
\hline \multirow[b]{2}{*}{ Patients } & \multirow[b]{2}{*}{ Age (y) } & \multirow[b]{2}{*}{ Bone age (y) } & \multirow[b]{2}{*}{ Baseline } & \multicolumn{3}{|c|}{ Treatment period (mo) } \\
\hline & & & & 6 & 12 & 24 \\
\hline 1 & 1.5 & 1.0 & 10.5 & 20.0 & 23.6 & \\
\hline 2 & 1.8 & 0.8 & 10.6 & 27.5 & 24.0 & 26.9 \\
\hline 3 & 2.6 & 1.5 & 8.3 & & 21.5 & 18.8 \\
\hline 4 & 2.5 & 1.5 & 22.0 & & 18.8 & 33.5 \\
\hline 5 & 3.7 & 2 & 14.9 & & 24.7 & 24.1 \\
\hline 6 & 3.8 & 3 & 19.4 & & 26.4 & 31.0 \\
\hline 7 & 3.9 & 2 & 7.3 & 11.0 & 24.9 & 27.9 \\
\hline 8 & 4.3 & 2 & 18.8 & 22.2 & 23.2 & \\
\hline 9 & 4.4 & 1.5 & 17.2 & & 18.5 & 20.3 \\
\hline 10 & 4.9 & 3 & 25.4 & 23.9 & & 25.4 \\
\hline 11 & 6.5 & 2.5 & 14.4 & 25.6 & 22.4 & \\
\hline 12 & 7.3 & 5 & 16.9 & & & 27.5 \\
\hline 13 & 7.8 & 4.5 & 7.0 & 7.9 & 15.0 & \\
\hline 14 & 8.0 & 4.0 & 16.6 & 14.5 & & \\
\hline 15 & 8.3 & 5.5 & 12.7 & 10.9 & & 23.4 \\
\hline 16 & 9.5 & 7.3 & 16.5 & 20.6 & & 41.4 \\
\hline 17 & 9.8 & 7.5 & 14.7 & 12.5 & 21.9 & \\
\hline 18 & 10.3 & 6.0 & 10.1 & 15.5 & 23.6 & \\
\hline Mean $\pm \mathrm{SEM}$ & $5.6 \pm 0.7$ & $3.4 \pm 0.5$ & $14.6 \pm 1.2$ & $17.7 \pm 1.9$ & $22.2 \pm 0.9$ & $27.3 \pm 1.9$ \\
\hline
\end{tabular}

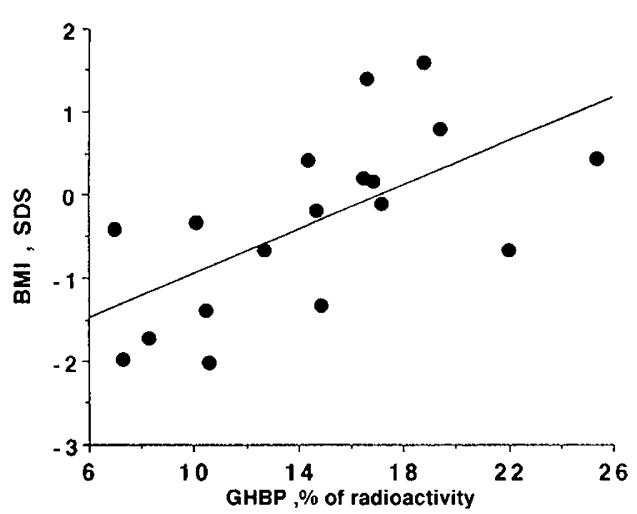

Figure 1. Relationship between BMI and serum GHBP levels in $18 \mathrm{GH}-$ deficient children. $r=0.63 ; p=0.005$.

tion was found between either GHBP and IGF-I levels or their increment under hGH therapy.

As expected, the growth velocity increased under hGH therapy, with a significant improvement in height. The mean BMI value was decreased after the first year of hGH treatment (Table 1). Neither the growth velocity before and under treatment nor the increase in the growth velocity during the studied period were correlated with GHBP or IGF-I levels before therapy. No correlation was observed between the increase in GHBP, IGF-I levels, and the growth velocity at 12 and 24 mo of hGH therapy.

\section{DISCUSSION}

This study l) confirms that GH-deficient children have a low plasma GH binding activity and 2) demonstrates that GH treatment normalizes GHBP levels progressively and that the increase in GHBP follows rather than precedes the increase in IGF-I plasma levels.

The low GHBP value found in this group of 18 children with isolated GH deficiency is comparable to the value that was reported previously by us (5) and by Tauber et al. (13). Normal

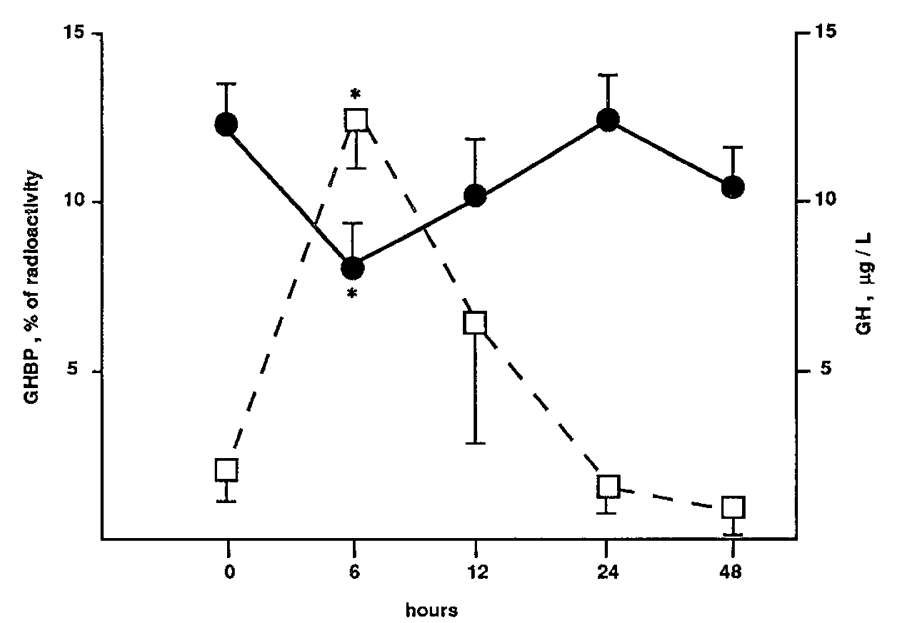

Figure 2. Serum GHBP $(\bullet)$ and GH $(\square)$ levels during the first $48 \mathrm{~h}$ of treatment. Each value represents the mean \pm SEM of results obtained in the patients. ${ }^{*} p<0.005 v s$ value at time 0 .

GHBP values were also found in GH-deficient children $(6,8)$. However, in the report by Hochberg et al. (6), the etiology of the GH deficiency has not been specified, and in the work of Martha et al. (8), one third of the patients presented associated deficiencies of several pituitary hormones. To have a group as homogeneous as possible, prepubertal children with isolated idiopathic GH deficiency were selected to be included in our study.

After the first hormone injection, elevated $\mathrm{GH}$ concentration at $6 \mathrm{~h}$ was accompanied by a decrease in GH binding activity. This result must be interpreted with caution as high GH concentrations interfere with GHBP determination because of receptor occupancy; even though correction was done for the high GH concentration, the GHBP levels at $6 \mathrm{~h}$ post-injection could have been somewhat underestimated. However, a decrease in the number of total GH binding sites has been demonstrated in liver membranes of hypophysectomized rats which had received a single injection of GH (14); this acute 
Table 3. GHBP values in 10 children with isolated GH deficiency, studied for the short-term hGH response

\begin{tabular}{|c|c|c|c|c|c|c|c|c|c|}
\hline \multirow[b]{2}{*}{ Patients } & \multirow[b]{2}{*}{ Age (y) } & \multirow{2}{*}{$\begin{array}{c}\text { Baseline } \\
\text { h } 0\end{array}$} & \multicolumn{7}{|c|}{ Treatment period } \\
\hline & & & h 6 & h 12 & h 24 & h 48 & d 8 & mo 1 & mo 3 \\
\hline 2 & 1.8 & 10.6 & 10.4 & 7.3 & 9.8 & 8.0 & & & 12.0 \\
\hline 3 & 2.6 & 8.3 & 1.5 & 4.4 & 8.8 & 7.5 & & 6.8 & 8.5 \\
\hline 7 & 3.9 & 7.3 & 5.4 & 7.1 & & 10.4 & 8.6 & 6.0 & 10.1 \\
\hline 12 & 7.3 & 16.9 & 8.9 & 12.9 & 18.6 & 15.8 & 13.7 & 16.3 & 13.5 \\
\hline 13 & 7.8 & 7.0 & 4.3 & & 7.3 & 6.9 & 5.1 & 6.1 & 12.5 \\
\hline 14 & 8.0 & 16.6 & 14.6 & 20.10 & 14.9 & 14.4 & & 9.6 & 16.1 \\
\hline 15 & 8.3 & 12.7 & 8.2 & 10.8 & 12.8 & 10.9 & 7.8 & 8.2 & 7.5 \\
\hline 16 & 9.5 & 16.5 & 8.6 & 11.5 & 12.8 & 14.1 & & 24.7 & 13.3 \\
\hline 17 & 9.8 & 14.7 & 11.6 & 11.6 & 16.2 & & 11.3 & 9.7 & 8.8 \\
\hline 18 & 10.3 & 10.1 & & 5.3 & 8.0 & 9.5 & 11.0 & 16.5 & 12.5 \\
\hline Mean \pm SEM & $6.9 \pm 0.9$ & $12.1 \pm 1.3$ & $8.2 \pm 1.3$ & $10.1 \pm 1.6$ & $12.1 \pm 1.3$ & $10.8 \pm 1.1$ & $9.6 \pm 1.2$ & $11.5 \pm 2.1$ & $11.5 \pm 0.9$ \\
\hline
\end{tabular}

GHBP values are expressed as the percentage of total radioactivity.

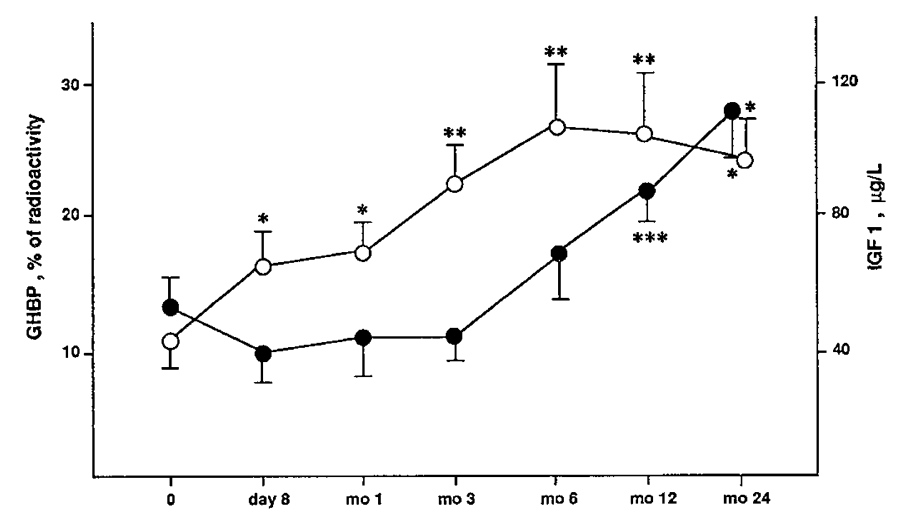

Figure 3. Evolution of the mean levels of GHBP $(\mathbf{O})$ and IGF-I $(O)$ during the first 24 mo of GH therapy. Normal values for the age group are: GHBP $=$ $24.8 \pm 1.7 \%$ of radioactivity, IGF-I $=100 \pm 5 \mu \mathrm{g} / \mathrm{L} .{ }^{*} p<0.02,{ }^{*} p<0.005$ *** $p<0.0001$ vs value at time 0 .

down-regulation of the liver membrane $\mathrm{GH}$ receptors contrasted with the up-regulation of $\mathrm{GH}$ receptors that was demonstrated during prolonged $\mathrm{GH}$ administration in rats (15).

Later, during the first week of treatment, no changes in the GHBP levels were observed for any of the patients. The length of time necessary for GH to induce GHBP was different from one patient to the other. It took 1-12 mo to observe this effect, which is certainly longer than the time necessary for the hormone to up-regulate the liver membrane $\mathrm{GH}$ receptors in rats (15). An age-related increase in GHBP has been shown in several reports $(11,16,17)$. However, in this group of $\mathrm{GH}$ deficient children, the effect of hGH therapy on GHBP is greater than the age effect observed in normal children (11) and in untreated children with idiopathic short stature, over a time period of 18 mo (7). No relationship was found between the effect of hGH on GHBP levels and the other responses to the treatment, such as the increase in serum IGF-I levels and in growth velocity.

In the study by Hochberg et al. (6), a progressive increase of GHBP during hGH therapy was also found in children with idiopathic GH deficiency, and the increase was observed sooner than in our group of children inasmuch as it was significant after 3 mo of treatment. But, in the recent report by Martha et al. (8), prepubertal GH-deficient children had normal basal GHBP levels and no consistent effect of the treatment on
GHBP was observed. Absence of GH effect on the GHBP levels could be explained by a lower dose of hGH which was given three times a week versus daily injections in our protocol. Moreover, the time of blood collection in relationship to the hormone injection, which might be critical to detect a GH effect on the GHBP level, was not specified (8). Another important recent study emphasizes the importance of the mode of hGH administration: in GH-deficient children, the $\mathrm{GH}$ effect on GHBP is more pronounced and more consistent with continuous infusion than with daily injections (13). Examples of up-regulation of GHBP by GH have been observed in children with growth disorders $(5-7,13)$. In children with isolated $\mathrm{GH}$ deficiency, a GH effect can be observed when the GHBP levels before treatment is low $(5,6,13)$ as is also found in the present study. The reason for a normal basal GHBP value in the study by Martha et al. (8) versus a low value in other studies including this one $(5,13)$, has to be clarified.

An inverse relationship has been shown between the high affinity serum GHBP and $24 \mathrm{~h}$ release of GH in boys aged 7-18 $\mathrm{y}$, under normal physiologic conditions (18). No discussion of the possible effect of other hormones, such as testosterone, was mentioned in this work, whereas GH and testosterone have been shown to have opposite effects on the regulation of GHBP (5). The mechanism by which GH affects the level of GHBP will not be clear before more is known about the generation of the binding protein.

A positive correlation between serum GHBP pretreatment levels and BMI was found in this study as in others (19-22), suggesting that nutritional factors affect BMI and GHBP in parallel. As expected, IGF-I levels increased significantly during the first 3 mo of hGH treatment, and they remained constant thereafter. IGF-I increment was not correlated to the growth velocity during the first $2 \mathrm{y}$ of treatment. These results are in accordance with previous reports $(23,24)$ which did not show correlation between linear growth velocity and IGF-I levels after chronic hGH administration to GH-deficient children. Neither the increase nor the absolute activity of IGF-I and GHBP were correlated, with large variations in individual responses.

Similar to membrane GH receptors, the serum GHBP level is controlled by multiple factors, among which $\mathrm{GH}$ plays an important role. The time course of the GH effect is progressive 
and variable. Thus, under the conditions of this study, it seems impossible to use the short-term effects of GH on the GHBP as a test to assess a hormonal or an auxologic response. A better knowledge of the biosynthesis and of the exact roles of the GHBP is needed to interpret the variations of the GH binding activity measured in human plasma.

Acknowledgment. The excellent technical assistance of Luc Sofer is gratefully acknowledged.

\section{REFERENCES}

1. Baumann G, Stolar MW, Amburn K, Barsano CP, De Vries BC 1986 A specific growth hormone-binding protein in human plasma: initial characterization. J Clin Endocrinol Metab 62:134-141

2. Leung DW, Spencer SA, Cachianes G, Hammonds RG, Collins C, Henzel WJ Barnard R, Waters MJ, Wood WI 1987 Growth hormone receptor and serum binding protein: purification, cloning and expression. Nature 330:537-543

3. Delehaye-Zervas MC, Mertani HC, Martini JF, Nihoul-Fekete C, Morel G, PostelVinay MC 1994 Growth hormone receptor gene expression in human digestive tissues. J Clin Endocrinol Metab 78:1473-1480

4. Kelly PA, Djiane J, Postel-Vinay MC, Edery M 1991 The prolactin/growth hormone receptor family. Endocr Rev 12:235-251

5. Postel-Vinay MC, Tar A, Hocquette JF, Clot JP, Fontoura M, Brauner R, Rappaport R 1991 Human plasma growth hormone $(\mathrm{GH})$ binding proteins are regulated by $\mathrm{GH}$ and testosterone. J Clin Endocrinol Metab 73:197-202

6. Hochberg Z, Barkey RJ, Even L, Peleg I, Youdim MBH, Amit T 1991 The effect of human growth hormone therapy on GH binding protein in $\mathrm{GH}$ deficient children. Acta Endocrinol 125:23-27

7. Fontoura M, Mugnier E, Brauner R, Rappaport R, Postel-Vinay MC 1992 Effect of growth hormone on the low level of growth hormone binding protein in idiopathic short stature. Clin Endocrinol 37:249-253

8. Martha PM, Reiter EO, Davila N, Shaw MA, Holcombe JH, Baumann G 1992 Serum growth hormone $(\mathrm{GH})$ binding protein/receptor: an important determinant of $\mathrm{GH}$ responsiveness. J Clin Endocrinol Metab 75:1464-1469

9. Sempe M, Pedron G, Roy-Pernot MP 1979 Auxologie, Méthode et Séquences. Theraplix, Paris

10. Rolland Cachera MF, Cole TJ, Sempe M, Tichet J, Rossignol C, Charraud A 1991 Body mass index variations: centiles from birth to 87 years. Eur J Clin Nutr 45:13-21
11. Tar A, Hocquette JF, Souberbielle JC, Clot JP, Brauner R, Postel-Vinay MC 1990 Evaluation of the growth hormone binding proteins in human plasma using high pressure liquid chromatography gel filtration. J Clin Endocrinol Metab 71:1202-1207

12. Binoux M, Seurin D, Lassare C, Gourmelen M 1984 Preferential measurements of insulin-like growth factor related peptides in serum with the aid of IGF binding proteins (IGFBPs) produced by rat liver in culture. Estimation of serum IGFBP levels. J Clin Endocrinol Metab 59:453-462

13. Tauber M, De Bouet, Du Portal H, Sallerin-Caute B, Rochiccioli P, Bastide R. 1993 Differential regulation of serum growth hormone-binding protein during continuous infusion versus daily injection of recombinant human $\mathrm{GH}$ in $\mathrm{GH}$-deficient children. $\mathbf{J}$ Clin Endocrinol Metab 76:1135-1139

14. Maiter D, Underwood LE, Maes M, Keterlslegers JM 1988 Acute down-regulation of the somatogenic receptors in rat liver by a single injection of growth hormone. Endocrinology 122:1291-1296

15. Baxter RC, Zalstman Z, Turtle JM 1984 Rat growth hormone but not prolactin induces both GH and PRL receptors in female rat liver. Endocrinology 114:18931901

16. Daughaday WH, Trivedi B, Andrews B.A 1987 The ontogeny of serum GH binding protein in man: a possible indicator of hepatic $\mathrm{GH}$ receptor development. J Clin Endocrinol Metab 6:1072-1074

17. Massa G, de Zegher F, Vanderschueren-Lodeweyckx M 1992 Serum growth hormone-binding proteins in the human fetus and infant. Pediatr Res 32:69-72

18. Martha PM, Rogol AD, Blizzard RM, Shaw MA, Baumann G 1991 Growth hormone binding protein activity is inversely related to 24 hours growth hormone release in normal boys. J Clin Endocrinol Metab 73:175-181

19. Martha PM, Reiter EO, Davila N, Shaw MA, Holcombe JH, Baumann G 1992 The role of body mass in the response to growth hormone therapy. J Clin Endocrinol Metab 75:1470-1473

20. Hochberg Z, Hertz P, Colin V 1992 The distal axis of growth hormone (GH) in nutritional disorders. GH binding protein, insulin-like growth factor I (IGF-I) and IGF-I receptors in obesity and anorexia nervosa. Metabolism 41:106-112

21. Silbergeld A, Lazar L, Erster B, Keret R, Tepper R, Laron Z 1989 Serum growth hormone binding protein activity in healthy neonates, children and young adults: correlation with age, height and weight. Clin Endocrinol 31:295-303

22. Massa G, Dooms L, Bouillon R, Vanderschueren-Lodeweyckx M 1993 Serum levels of growth hormone-binding protein and insulin-like growth factor $\mathrm{I}$ in children and adolescents with type 1 (insulin-dependent) diabetes mellitus. Diabetologia 36:239243

23. Rosenfeld RG, Kemp SF, Hintz RF 1981 Constancy of somatomedin response to growth hormone treatment of hypopituitary dwarfism, and lack of correlation with growth rate. J Clin Endocrinol Metab 53:611-617

24. Dean HJ, Kellet JG, Bala RM, Guyda HJ, Bhaumick B, Posner BI, Friesen HG 1982 The effect of growth hormone treatment on somatomedin levels in growth hormone deficient children. J Clin Endocrinol Metab 55:1167-1173 